\title{
Electronic Denitration Savannah River Site Radioactive Waste (U)
}

by

D. T. Hobbs

Westinghouse Savannah River Company

Savannah River Site

Aiken, South Carolina 29808

DOE Contract No. DE-AC09-89SR18035

This paper was prepared in connection with work done under the above contract number with the U. S. Department of Energy. By acceptance of this paper, the publisher and/or recipient acknowledges the U.S. Government's right to retain a nonexclusive, royalty-free license in and to any copyright covering this paper, along with the right to reproduce and to authorize others to reproduce all or part of the copyrighted paper.

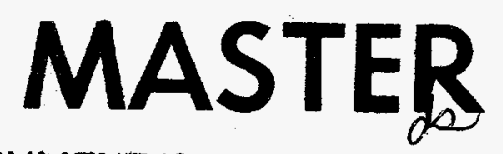




\section{DISCLATMER}

This report was prepared as an account of work sponsored by an agency of the United States Government.' Neither the United States Government nor any agency thereof, nor any of their employees, makes any warranty, express or implied, or assumes any legal liability or responsibility for the accuracy, completeness, or usefulness of any information, apparatus, product, or process disclosed, or represents that its use would not infringe privately owned rights. Reference herein to any specific commercial product, process, or service by trade name, trademark, manufacturer, or otherwise does not necessarily constitute or imply its endorsement, recommendation, or favoring by the United States Government or any agency thereof. The views and opinions of authors expressed herein do not necessarily state or reflect those of the United States Government or any agency thereof.

This report has been reproduced directly from the best available copy.

Available to DOE and DOE contractors from the Office of Scientific and Technical Information, P.O. Box 62, Oak Ridge, TN 37831; prices available from (615) 576-8401.

Available to the public from the National Technical Information Service, U.S. Department of Commerce, 5285 Port Royal Road, Springfield, VA 22161. 


\section{DISCLAIMER}

Portions of this document may be illegible in electronic image products. Images are produced from the best available original document. 
WSRC-TR-95-0176

Keywords: ETF, Nitrate, Nitrite, Destruction, Caustic, Solution, Cathode, Anode

Retention Time: permanent

\section{Electrolytic Denitration of Radioactive Savannah River Site Waste (U)}

April 26, 1995

Westinghouse Savannah River Company

P.O. Box 616

Aiken, SC 29802

Prepared for the Department of Energy Office of Technology Development, Office of Environmental Management under Contract DE-AC09-8\&SR 18035 


\title{
Electrolytic Denitration of Radioactive Savannah River Site Waste (U)
}

\author{
by \\ D. T. Hobbs \\ D.T.
}

April 26, 1995

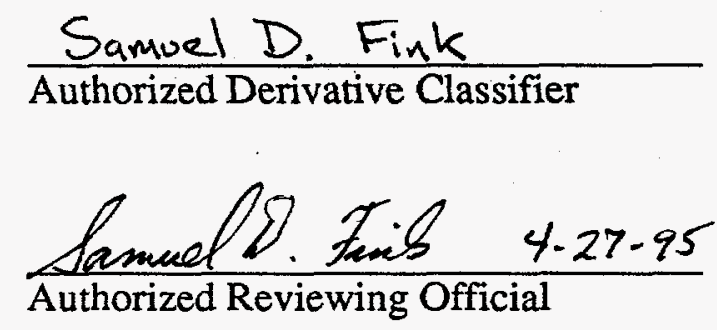

Savannah River Technology Center

Westinghouse Savannah River Company

Aiken, SC 29802

Prepared for the Department of Energy Office of Technology Development, Office of Environmental Management under Contract DE-AC09-8\$SR 18035 


\section{SUMMARY}

Electrochemical destruction of nitrate in radioactive Savannah River Site waste has been demonstrated in a bench-scale flow cell reactor. Greater than $99 \%$ of the nitrate can be destroyed in either an undivided or a divided cell reactor. The rate of destruction and the overall power consumption is dependent on the cell configuration and electrode materials. The fastest rate was observed using an undivided cell equipped with a nickel cathode and nickel anode. The use of platinized titanium anode increased the energy requirement and costs compared to a nickel anode in both the undivided and divided cell configurations.

\section{INTRODUCTION}

Production of nuclear materials within the Department of Energy complex has produced large volumes of high-level waste containing hazardous species such as nitrate, nitrite, chromium, and mercury. Processes being developed for the permanent disposal of these wastes are aimed at. separating the bulk of the radioactivity, primarily ${ }^{137}$ cesium and ${ }^{90}$ strontium, into a small volume for incorporation into a vitrified wasteform, with the remainder being incorporated into a low-level wasteform. Performance assessments of the low-level wasteforms indicate that major contributors to environmental release and personnel exposure risks include nitrate, nitrite, ${ }^{99}$ technetium and 106ruthenium.

Electrochemical treatment is one possible technology for the destruction of nitrate and nitrite as well as the removal of radionuclides and hazardous metals from the waste solutions. In the electrochemical reactor, nitrate and nitrite are reduced to nitrogen-containing gases: nitrous oxide, nitrogen and ammonia. Half-cell reactions are shown below.

$$
\begin{array}{lll}
\mathrm{NO}_{3}^{-}+\mathrm{H}_{2} \mathrm{O}+2 \mathrm{e}^{-}= & \mathrm{NO}_{2}^{-}+2 \mathrm{OH}^{-} \\
2 \mathrm{NO}_{2}^{-}+3 \mathrm{H}_{2} \mathrm{O}+4 \mathrm{e}^{-}= & \mathrm{N}_{2} \mathrm{O}+6 \mathrm{OH}^{-} \\
2 \mathrm{NO}_{2}^{-}+4 \mathrm{H}_{2} \mathrm{O}+6 \mathrm{e}^{-}= & \mathrm{N}_{2}+8 \mathrm{OH}^{-} \\
\mathrm{NO}_{2}^{-}+5 \mathrm{H}_{2} \mathrm{O}+6 \mathrm{e}^{-}= & \mathrm{NH}_{3}+7 \mathrm{OH}^{-}
\end{array}
$$

These gases have very low solubility in the alkaline salt solution and are released into the vapor phase, thus separating from the solution. In an undivided cell, the corresponding anode reaction is the oxidation of hydroxide to oxygen and water.

$$
4 \mathrm{OH}^{-}=\mathrm{O}_{2}+2 \mathrm{H}_{2} \mathrm{O}+4 \mathrm{e}^{-}
$$

The net electrochemical reduction of nitrate or nitrite would then produce one equivalent of hydroxide per nitrate or nitrite reduced. Note that there are no additional chemicals added to the waste as a result of the electrochemical treatment.

Previous studies have demonstrated the electrochemical destruction of nitrate and nitrite in bench-scale flow cell reactors with simulated waste solutions [1-4] and in an unstirred batch cell with Savannah River Site (SRS) decontaminated salt solution [5]. This report summarizes the results of bench-scale tests carried out in a flow cell reactor with a lowlevel radioactive waste produced in the Effluent Treatment Facility (ETF) at the SRS. 


\section{EXPERIMENTAL}

A 10 gallon sample of the strongly alkaline radioactive waste was obtained from the ETF and used for all of the tests. The liquid phase composition of the slurry is shown in Table I. Major components included nitrate, hydroxide and sodium. The carbonate and nitrite concentrations in this waste are low compared to high-level liquid wastes since this waste has not been stored for the extended period time that allows the absorption of atmospheric carbon dioxide and the radiolytic conversion of nitrate to nitrite. The sample contained $0.5 \mathrm{wt} \%$ undissolved solids. Using X-ray fluorescence spectroscopy, the solids were determined to be comprised of strontium, uranium, zinc, iron, nickel, barium, platinum, and bromine. X-ray diffraction patterns identified the following crystalline phases: sodium nitrate, sodium calcium carbonate, and sodium aluminum nitrate silicate hydrate.

\section{Table I. Composition and Properties of the Effluent Treatment Facility Concentrate}

$\begin{array}{lc}\text { Species or Property } & \begin{array}{c}\text { Concentration * } \\ \text { Nitrate }\end{array} \\ \text { Nitrite } & <.57 \pm 0.10 \mathrm{M} \\ \text { Sulfate } & 2.17 \times 10^{-2} \mathrm{M} \\ \text { Phosphate } & 9.57 \pm 0.078 \times 10^{-2} \mathrm{M} \\ \text { Oxalate } & 9.10 \pm 0.12 \times 10^{-4} \mathrm{M} \\ \text { Fluoride } & 9.67 \pm 0.14 \times 10^{-3} \mathrm{M} \\ \text { Chloride } & 2.89 \pm 0.19 \times 10^{-4} \mathrm{M} \\ \text { Hydroxide } & 4.15 \pm 0.25 \times 10^{-2} \mathrm{M} \\ \text { Aluminate } & 1.41 \pm 0.16 \mathrm{M} \\ \text { Carbonate } & 9.70 \pm 1.7 \times 10^{-2} \mathrm{M} \\ \text { Sodium } & 1.43 \pm 0.69 \times 10^{-2} \mathrm{M} \\ \text { Silicon } & 5.19 \pm 0.054 \mathrm{M} \\ \text { Zinc } & 1.35 \pm 0.068 \times 10^{-3} \mathrm{M} \\ \text { Cs-137 } & 1.17 \pm 0.010 \times 10^{-3} \mathrm{M} \\ \text { Density } & 1.37 \pm 0.23 \times 10^{-3} \mathrm{mCi} / \mathrm{L} \\ \text { * average and standard deviation of three samples taken from the } \\ \text { top, middle, and bottom of sample bottle. }\end{array}$

The electrochemical destruction tests were carried out in a laboratory-scale flow reactor, the FM01-LC, manufactured by ICI (Great Britain). This electrochemical cell has a working electrode surface area of $0.0064 \mathrm{~m}^{2}$. The test equipment included the electrochemical reactor, two rotameters (PVDF shell with EPPM sealing O-rings, two March model \#TE-MDK-MT3 centrifugal pumps (PVDF-lined), one $2.5 \mathrm{~L}$ glass reservoir for catholyte solution, and one Nalgene ${ }^{\circledR} 10 \mathrm{~L}$ carboy for the anolyte reservoir. Electrical power was supplied by a Hewlett-Packard Model \# 6011-A dc power supply. Each reservoir was equipped with a glass condenser. A schematic diagram of the test 
equipment is provided in Figure 1. A photograph of the experimental equipment is shown in Figure 2.

All of the tests were carried out under galvanostatic (i.e., constant current) control. During the later stages of some of the tests, when a significant fraction of the nitrate has been destroyed, the current density was decreased to maintain the same power supply voltage (see Table II). The catholyte temperatures were not controlled; the solution heated to between 33 and $53^{\circ} \mathrm{C}$ (see Table II). Typically, the temperature reached steady-state conditions within two hours of the start of each test. Flowrates, temperatures, voltage, and current were monitored on a periodic basis.

Catholyte and anolyte samples were taken periodically during each test. Ion chromatographic and inductively-coupled plasma emission spectroscopic methods were utilized to determine chemical composition of each sample. Over the course of a test, the catholyte flowrate generally decreased by about $20 \%$. The anolyte flowrate was decreased to maintain the same flowrate as the catholyte.

For tests conducted in an undivided cell configuration the anolyte reservoir, pump and rotameter were isolated from the system and not used. The catholyte reservoir was continuously purged with argon at a flowrate of $0.050 \mathrm{~L} / \mathrm{min}$ to dilute flammable gases below the lower flammable limit. Divided cell tests were conducted by placing a piece of Nafion ${ }^{\circledR}$ Type 350 membrane between the two electrodes. The membrane was held in place by compression between two gaskets. No turbulence promoters were installed in tests ED-11, ED-12, and ED-13, or the undivided cell tests, ED-19 through Ed-23, but were installed in tests ED-14, ED-15, ED-17, and ED-18.

Figure 1. Schematic Diagram of the Radioactive Bench-Scale Test Equipment

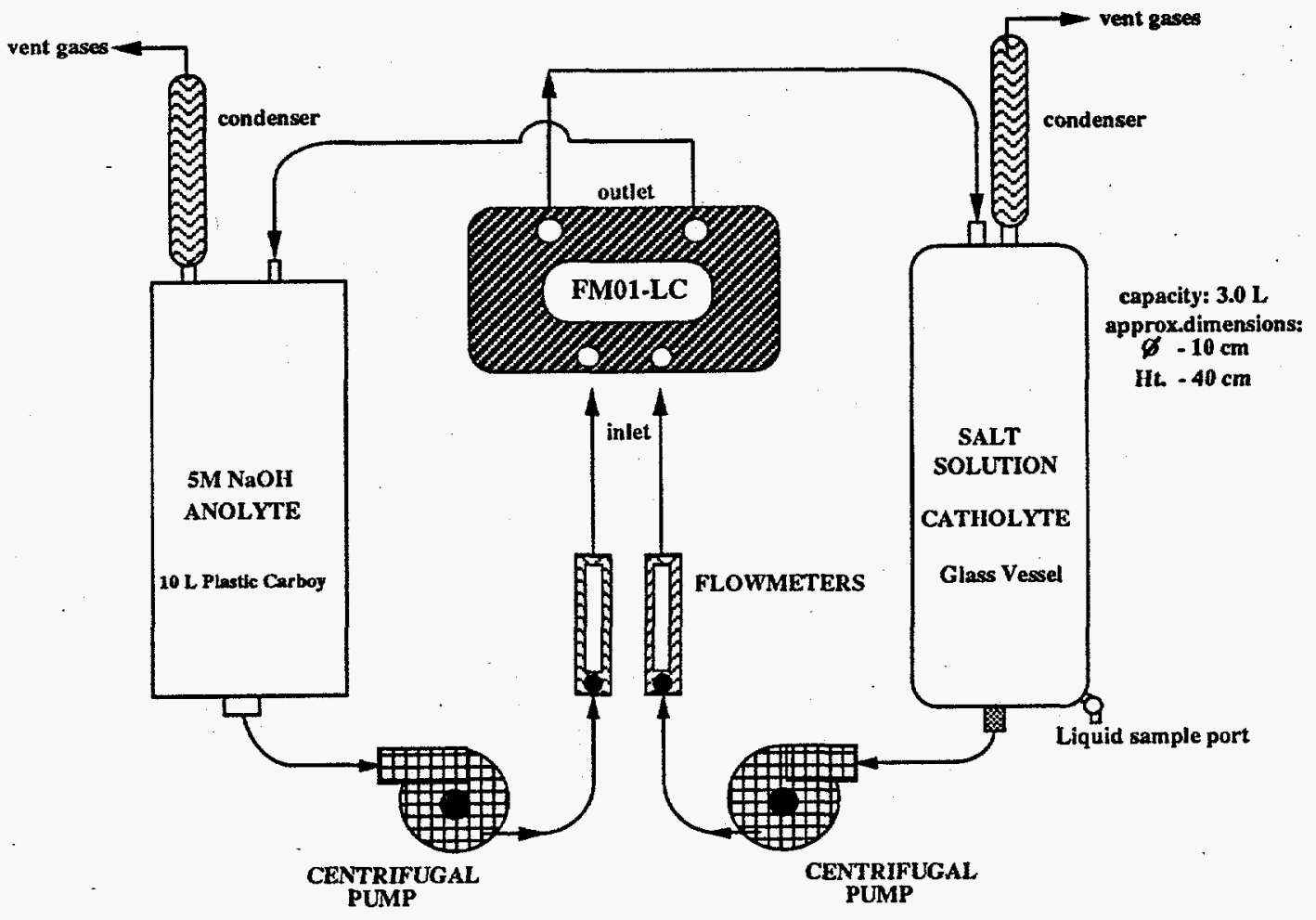


Figure 2. Photograph of the Radioactive Bench-Scale Testing Equipment

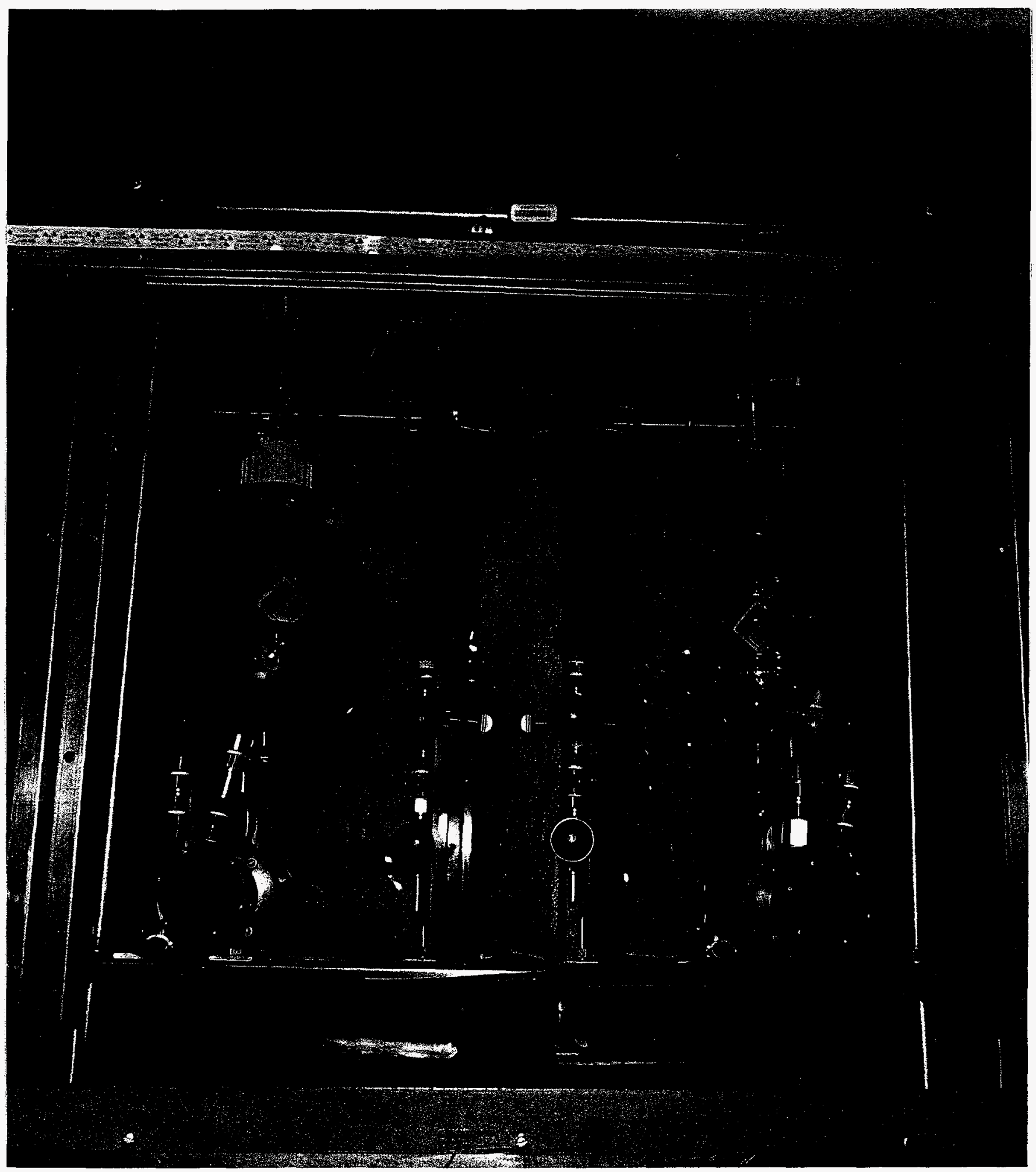




\section{RESULTS AND DISCUSSION}

A total of thirteen tests were carried out with the ETF concentrate. Seven of the tests were carried out in a divided configuration and six of the tests. were carried out in undivided configuration. Cathode materials tested included nickel, Type 316 stainless. steel, and lead. Anode materials tested included nickel and platinized-titanium. Current densities ranged from 2500 to $5000 \mathrm{amp} / \mathrm{m}^{2}$. Table II provides a summary of the test conditions for each of the tests.

\section{Divided Cell Tests}

Tests ED-11, ED-12, and ED-13 were consecutive experiments in which fresh ETF concentrate and $5 \mathrm{M} \mathrm{NaOH}$ solution was added to the test equipment after draining the solutions at the conclusion of the previous test. The objective of the consecutive tests was to demonstrate the reproducibility of the nitrate destruction. In tests ED-11 and ED12 , the power supply current was decreased during the later stages of each test due to an increase in the voltage as a result of the depletion of nitrate and nitrite. After 16 hours of electrolysis in ED-13, the test was stopped when erratic voltage spikes occurred. All of . the test solution was drained from the equipment, and the cell disassembled and inspected.

The cathode had a black film on the working area of the electrode that was not easily removed by wiping. The membrane had been pushed against the anode. Black solids surrounded with a green film were deposited in the Nafion ${ }^{\circledR}$ membrane. Small pits were observed on the anode opposite of where the black solids were found in the membrane. The inlet and outlet manifolds for the catholyte and anolyte showed no signs of attack or accumulation of solids.

Apparently, during the third test, ED-13, the membrane was pushed against the anode. The cause of the membrane being pushed against the anode is unknown. It is believed that the membrane was not completely taut when the cell was assembled and as a result of a higher pressure on the catholyte side of membrane, the membrane was pushed onto the anode. Note that turbulence promoters, which would have prevented the membrane from contacting the anode, were not used in these tests to reduce the possibility of solids accumulation.

In those areas where the membrane contacted the membrane, localized changes in the $\mathrm{pH}$ occurred, resulting in a sufficiently low $\mathrm{pH}$ that attack of the nickel occurred as evidenced by the pitting. The nickel precipitated as the pale green nickel hydroxide. Some of the nickel migrated into and across the membrane and was reduced to the black solid, nickel. For all other tests, turbulence promoters were installed on both sides of the membrane. No evidence of attack of any of the electrodes was observed with turbulence promoters installed. 
Table II. Summary of Radioactive Testing Conditions

\begin{tabular}{|c|c|c|c|c|c|c|c|}
\hline Test \# & Config ${ }^{a}$ & Cathode & Anode & $\begin{array}{l}\text { Catholyte } \\
\text { Flowrate } \\
\text { (gpm) }\end{array}$ & $\begin{array}{c}\text { Voltagec } \\
(\mathrm{V})\end{array}$ & $\begin{array}{l}\text { Current } \\
\text { Density } \\
\left(\mathrm{A} / \mathrm{m}^{2}\right)\end{array}$ & $\begin{array}{l}\text { Catholyte } \\
\text { Temp. }\left({ }^{\circ} \mathrm{C}\right)\end{array}$ \\
\hline ED-11 & divided & $\mathrm{Ni}$ & $\mathrm{Ni}$ & $\begin{array}{l}1.1-1.3 \\
1.0\end{array}$ & $\begin{array}{l}5.0-5.7 \\
5.1\end{array}$ & $\begin{array}{l}5000 \\
3940\end{array}$ & $\begin{array}{l}39-43 \\
39\end{array}$ \\
\hline \multirow[t]{2}{*}{ ED-12 } & \multirow[t]{2}{*}{ divided } & \multirow[t]{2}{*}{$\mathrm{Ni}$} & \multirow[t]{2}{*}{$\mathrm{Ni}$} & $1.1-1.2$ & $4.6-5.1$ & 5000 & $36-42$ \\
\hline & & & & $1.1-1.2$ & $4.6-4.7$ & 4060 & $36-38$ \\
\hline ED-13 & divided & $\mathrm{Ni}$ & $\mathrm{Ni}$ & $1.1-1.2$ & $4.6-5.0$ & 5000 & $35-39$ \\
\hline ED-14 & divided & $\mathrm{Ni}$ & $\mathrm{Ni}$ & $\begin{array}{l}1.2-1.3 \\
1.2 \\
1.1 \\
1.1\end{array}$ & $\begin{array}{l}4.6-5.0 \\
4.7-4.8 \\
4.6-5.0 \\
4.7\end{array}$ & $\begin{array}{l}3500 \\
3120 \\
2810 \\
2500\end{array}$ & $\begin{array}{l}35-40 \\
35-36 \\
34-36 \\
34-35\end{array}$ \\
\hline ED-15 & divided & $\mathrm{Ni}$ & $\mathrm{Pt}-\mathrm{Ti}^{\mathrm{d}}$ & $\begin{array}{l}0.9-1.0 \\
0.9-1.0 \\
1.0 \\
1.0\end{array}$ & $\begin{array}{l}6.0-6.1 \\
5.9-6.0 \\
5.9-6.0 \\
5.0-6.0\end{array}$ & $\begin{array}{l}3500 \\
3050 \\
2730 \\
2500\end{array}$ & $\begin{array}{l}34-39 \\
39 \\
37-38 \\
37\end{array}$ \\
\hline \multirow[t]{2}{*}{ ED-17 } & \multirow[t]{2}{*}{ divided } & \multirow[t]{2}{*}{$316 S^{e}$} & \multirow[t]{2}{*}{$\mathrm{Pt}-\mathrm{Ti}^{\mathrm{d}}$} & $\begin{array}{l}0.9-1.0 \\
0.9 \\
0.8\end{array}$ & $\begin{array}{l}5.7-6.0 \\
5.8-6.0 \\
5.9-6.0\end{array}$ & $\begin{array}{l}3500 \\
3170 \\
2890\end{array}$ & $\begin{array}{l}35-37 \\
37 \\
36\end{array}$ \\
\hline & & & & 0.8 & 5.9 & 2660 & 35 \\
\hline \multirow[t]{2}{*}{ ED-18 } & \multirow[t]{2}{*}{ divided } & \multirow[t]{2}{*}{$316 S^{e}$} & \multirow[t]{2}{*}{$\mathrm{Ni}$} & $\begin{array}{l}0.7-0.9 \\
0.7 \\
0.7 \\
0.7\end{array}$ & $\begin{array}{l}4.9-5.0 \\
4.9-5.0 \\
5.0 \\
4.9-5.0\end{array}$ & $\begin{array}{l}3500 \\
3310 \\
3140 \\
2940\end{array}$ & $\begin{array}{l}34-37 \\
37 \\
37 \\
37\end{array}$ \\
\hline & & & & 0.7 & $4.9-5.0$ & 2700 & 37 \\
\hline ED-19 & undivided & $\mathrm{Ni}$ & $\mathrm{Ni}$ & $1.3-1.4$ & 3.3-3.7 & 5000 & $33-44$ \\
\hline ED-20 & undivided & $\mathrm{Ni}$ & $\mathrm{Pt}-\mathrm{Ti}^{\mathrm{d}}$ & $1.3-1.4$ & $4.6-4.7$ & 5000 & $44-49$ \\
\hline ED-21 & undivided & $316 S^{e}$ & $\mathrm{Ni}$ & $1.3-1.4$ & $3.3-3.5$ & 5000 & $38-45$ \\
\hline ED-22 & undivided & $316 \mathrm{SS}^{\mathrm{e}}$ & $\mathrm{Pt}-\mathrm{Ti}^{\mathrm{d}}$ & $1.3-1.4$ & $4.6-4.7$ & 5000 & $44-53$ \\
\hline ED-23 & undivided & $\mathrm{Pb}$ & $\mathrm{Ni}$ & $1.3-1.4$ & $3.4-3.7$ & 5000 & $39-45$ \\
\hline ED-24 & undivided & $\mathrm{Pb}$ & $P t-T^{d}$ & $1.3-1.4$ & $4.6-4.8$ & 5000 & $44-51$ \\
\hline & $\begin{array}{l}\text { a Nafion@ Ty } \\
\text { solution wa } \\
\text { b Flowrate ra } \\
\text { c Voltage of } \\
\text { the first 1- } \\
\text { d Platinized t } \\
\text { e Type } 316 \mathrm{~S}\end{array}$ & $\begin{array}{l}350 \text { membr } \\
\text { used as the an } \\
\text { ge during inte } \\
\text { c power supp } \\
\text { hours of the to } \\
\text { anium electro } \\
\text { inless Steel }\end{array}$ & $\begin{array}{l}\text { ysed as } \\
\text { yte and th } \\
\text { al of oper } \\
\text { and incluo } \\
\text { manufact }\end{array}$ & $\begin{array}{l}\text { jarator. In } \\
\text { TF concent } \\
\text { on at the sar } \\
\text { voltage dur } \\
\text { d by ICI (M }\end{array}$ & $\begin{array}{l}\text { ided cell test } \\
\text { as the cath } \\
\text { current dens } \\
\text { time solutic } \\
\text { cote ES1) }\end{array}$ & neating up & ing \\
\hline
\end{tabular}


Figure 3 shows a plot of the nitrate and nitrite concentration versus charge passed for tests ED-11, ED-12, and ED-13. The nitrate concentration steadily decreased with increasing charge passed through the cell. The nitrite concentration increased to about 0.15 molar, and then decreased with continued cell operation and charge passed. Based on the net change in moles of nitrate and nitrite and the total charge passed for each test, the rate of destruction was determined to be $1.5 \times 10^{-6}, 1.5 \times 10^{-6}$, and $1.6 \times 10^{-6}$ moles/coulomb for tests ED-11, ED-12, and ED-13, respectively. Until, the attack of the anode occurred during the third test, the electrochemical destruction of nitrate in the ETF concentrated was very reproducible in the FM01-LC flow reactor.

Figure 3. Nitrate and Nitrite Concentrations Versus Total Charge for Tests ED-11, ED-12, and ED-13

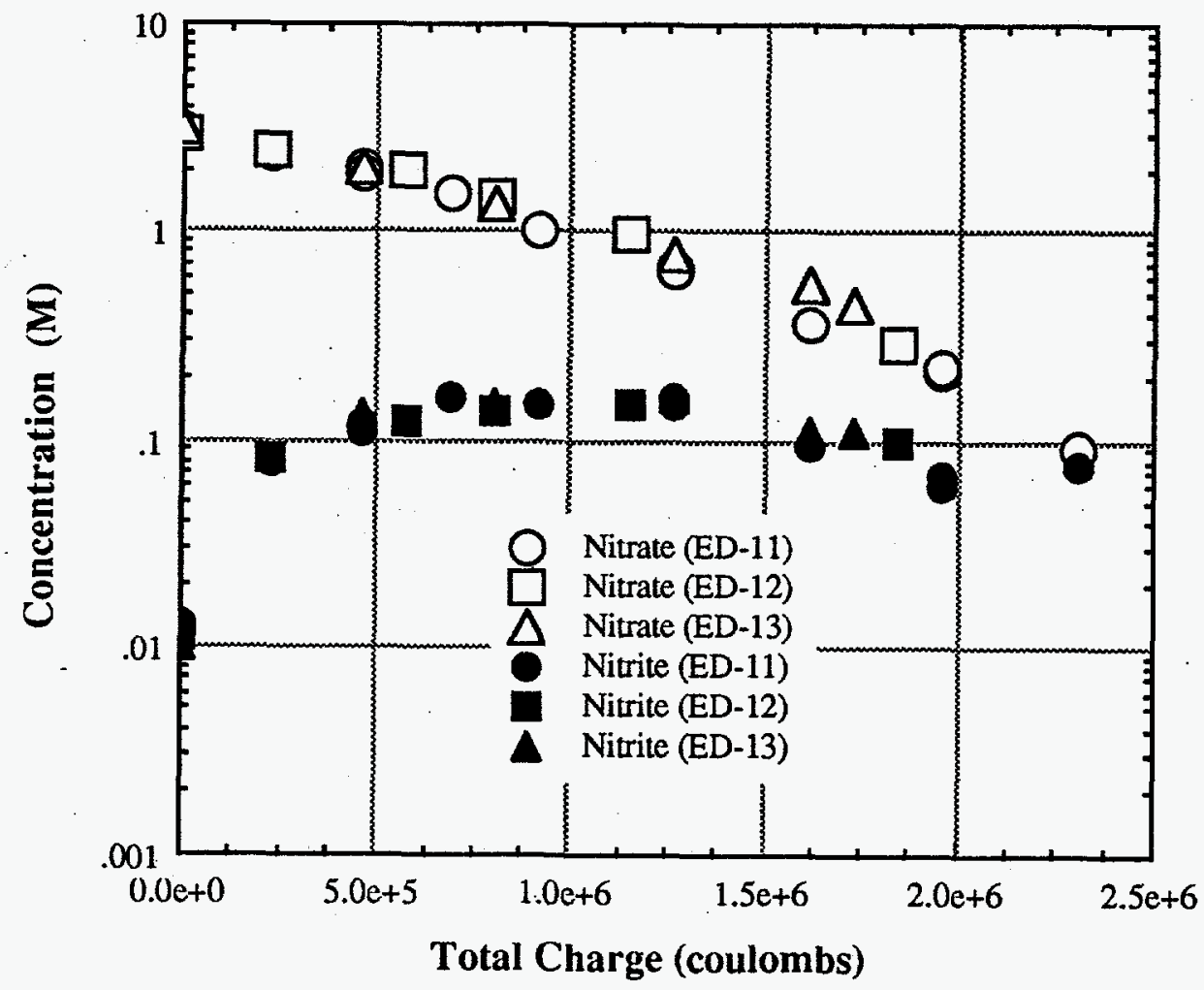

The total amount of nitrate and nitrite destroyed in tests ED-11, ED-12, and ED-13 ranged from $93.9 \%$ to $77.8 \%$ (mole basis). The difference in nitrate and nitrite destroyed was due to the length of the test (total charge passed). The hydroxide concentration in the catholyte ranged from $10.4 \mathrm{M}$ to $9.6 \mathrm{M}$. There was a net increase in the catholyte volume during each test. The anolyte volume and hydroxide concentration decreased significantly during each test. Anolyte and catholyte volumes and component concentrations for each are summarized in Table III. 
Table III. Catholyte and Anolyte Volumes and Major Component Concentrations for Tests \# ED-11, ED-12, and Ed-13

\begin{tabular}{|c|c|c|c|}
\hline Test \# & ED-11 & ED-12 & ED-13 \\
\hline Total Run Time (hr) & 21 & 19 & 16 \\
\hline Total Charge Passed (coulombs) & $2.30 \times 10^{6}$ & $2.19 \times 10^{6}$ & $1.73 \times 10^{6}$ \\
\hline Initial Catholyte Volume (L) & 1.2 & 1.3 & 1.2 \\
\hline Final Catholyte Volume (L) & 1.4 & 1.6 & 1.6 \\
\hline Initial Catholyte $\left[\mathrm{NO}_{3}{ }^{-}\right](\mathrm{M})$ & 3.06 & 2.98 & 3.12 \\
\hline Final Catholyte $\left[\mathrm{NO}_{3}{ }^{-}\right](\mathrm{M})$ & 0.09 & 0.29 & 0.45 \\
\hline Initial Catholyte $\left[\mathrm{NO}_{2}^{-}\right](\mathrm{M})$ & 0.013 & 0.010 & 0.010 \\
\hline Final Catholyte $\left[\mathrm{NO}_{2}{ }^{-}\right](\mathrm{M})$ & 0.077 & 0.099 & 0.11 \\
\hline Initial Catholyte $\left[\mathrm{OH}^{-}\right](\mathrm{M})$ & 2.4 & 2.7 & 2.4 \\
\hline Final Catholyte $\left[\mathrm{OH}^{-}\right](\mathrm{M})$ & 10.4 & 9.9 & 9.6 \\
\hline $\begin{array}{l}\text { Initial Anolyte Volume (L) } \\
\text { Final Anolyte Volume (L) }\end{array}$ & $\begin{array}{l}4.6 \\
2.8\end{array}$ & $\begin{array}{l}4.1 \\
2.8\end{array}$ & $\begin{array}{l}4.3 \\
3.5\end{array}$ \\
\hline Initial Anolyte $\left[\mathrm{OH}^{-}\right](\mathrm{M})$ & 4.7 & 4.8 & 5.1 \\
\hline Final Anolyte $\left[\mathrm{OH}^{-}\right](\mathrm{M})$ & 2.4 & 3.0 & 3.4 \\
\hline
\end{tabular}

Test ED-14 was similar to the previous tests with the exceptions of (1) the addition of turbulence promoters, (2) the nickel anode was reversed to expose an unattacked surface, and (3) the initial current density was reduced to $3500 \mathrm{amps} / \mathrm{m}^{2}$. This test was carried out for a total of 56 hours during which $99.9 \%$ of the nitrogen originally present as nitrate and nitrite was removed from solution. Tests ED-15, ED-17, and ED-18 were similar to ED-14 except that different cathode and anode materials were utilized (see Table II for conditions). Table IV provides a summary of the catholyte and anolyte volumes and major component concentrations for these tests.

The cell voltage in the divided cell tests was independent of cathode material, but was dependent on the anode material. The voltage was about 1.0 volts higher when platinized titanium was used than when nickel was used. Thus, at a current density of 3500 amps $/ \mathrm{m}^{2}$, the electrical power requirement for a reactor equipped with platinized titanium anodes would consume about $20 \%$ more power than one equipped with nickel anodes. 
Table IV. Catholyte and Anolyte Volumes and Major Component Concentrations for Tests \# ED-14, ED-15, ED-17, and ED-18

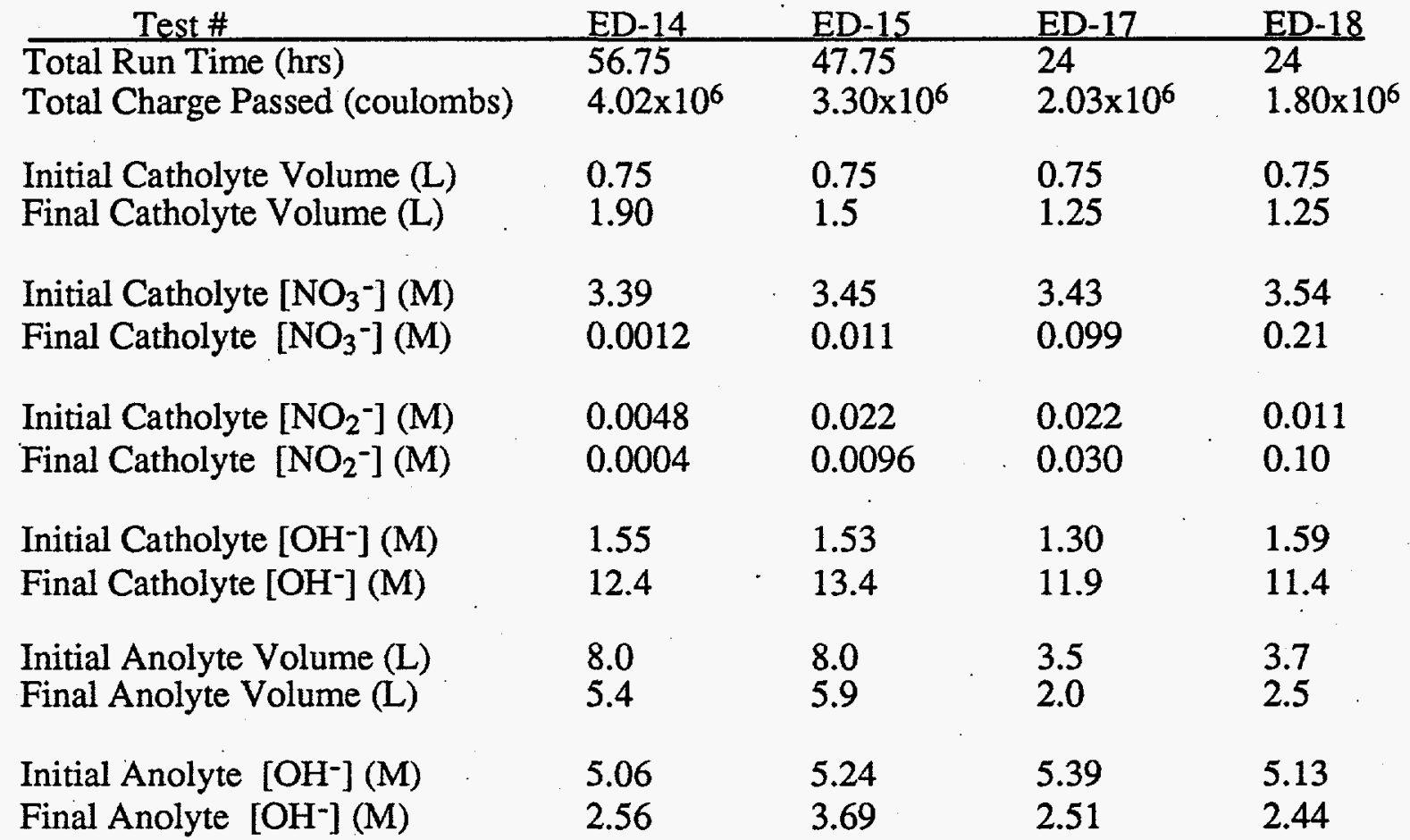

The total moles of nitrate and nitrite were plotted versus the total charge passed for tests ED-14, ED-15, ED-17, and ED-18 (see Figure 4). During the first $2 \times 10^{6}$ coulombs of charge, about $90 \%$ of the nitrate and nitrite is destroyed. From a linear regression of the data over this period, the rate of nitrate and nitrite destruction for each of the four tests was determined. The results are provided in Table V. In the divided cell configuration, there was no significant change in the rate of nitrate destruction among the four combinations of electrode materials. The destruction rates in the divided cell tests with turbulence promoters were about $30 \%$ lower than those without turbulence promoters (ED-11, ED-12, and ED-13). The decrease in the destruction rate is believed to be due to decreased mass transport resulting from the generally lower flowrate (see Table II).

Table V. Rate of Nitrate \& Nitrite Destruction in Divided Cell Tests

\begin{tabular}{|c|c|c|}
\hline Test \# & $\mathrm{k}(\mathrm{mole} / \mathrm{C})$ & $\begin{array}{l}\text { Currenta } \\
\text { Efficiency }(\%)\end{array}$ \\
\hline ED-14 & $1.17 \times 10^{-6}$ & 57 \\
\hline ED-15 & $1.09 \times 10^{-6}$ & 53 \\
\hline ED-17 & $1.20 \times 10^{-6}$ & 58 \\
\hline ED-18 & $1.15 \times 10^{-6}$ & 56 \\
\hline
\end{tabular}


The nitrate destruction rates observed with the SRS waste are greater than those measured in simulants of concentrated salt solutions [1,2]. It is possible that the higher rates and the lack of variation in rate with different electrode materials in these tests reflect the low chromium (VI) concentration in the ETF concentrate sample. Laboratory tests have indicated that chromium(VI) is reduced and forms $\mathrm{Cr}$ (III) hydroxide films on the electrode surface that interfere with nitrate and nitrite reduction $[2,7,8]$.

Inspection of the cell components after each test showed no evidence of attack of the electrodes, the ion-exchange membrane, or the other cell components. There was no accumulation of the undissolved solids in the cell that restricted the flow of solution. Surface films were observed on the electrodes in contact with solutions. A description of the appearance of the films is provided in Table VI. The black films strongly adhered to the cathodes and were not removed by rinsing with deionized, distilled water or detergent and water. The films were removed by briefly soaking and rinsing the cathode and anode in $2 \mathrm{M}$ nitric acid.

Figure 4. Total Moles of Nitrate \& Nitrite Versus Total Charge for Tests ED-14, ED-15, ED-17, and ED-18

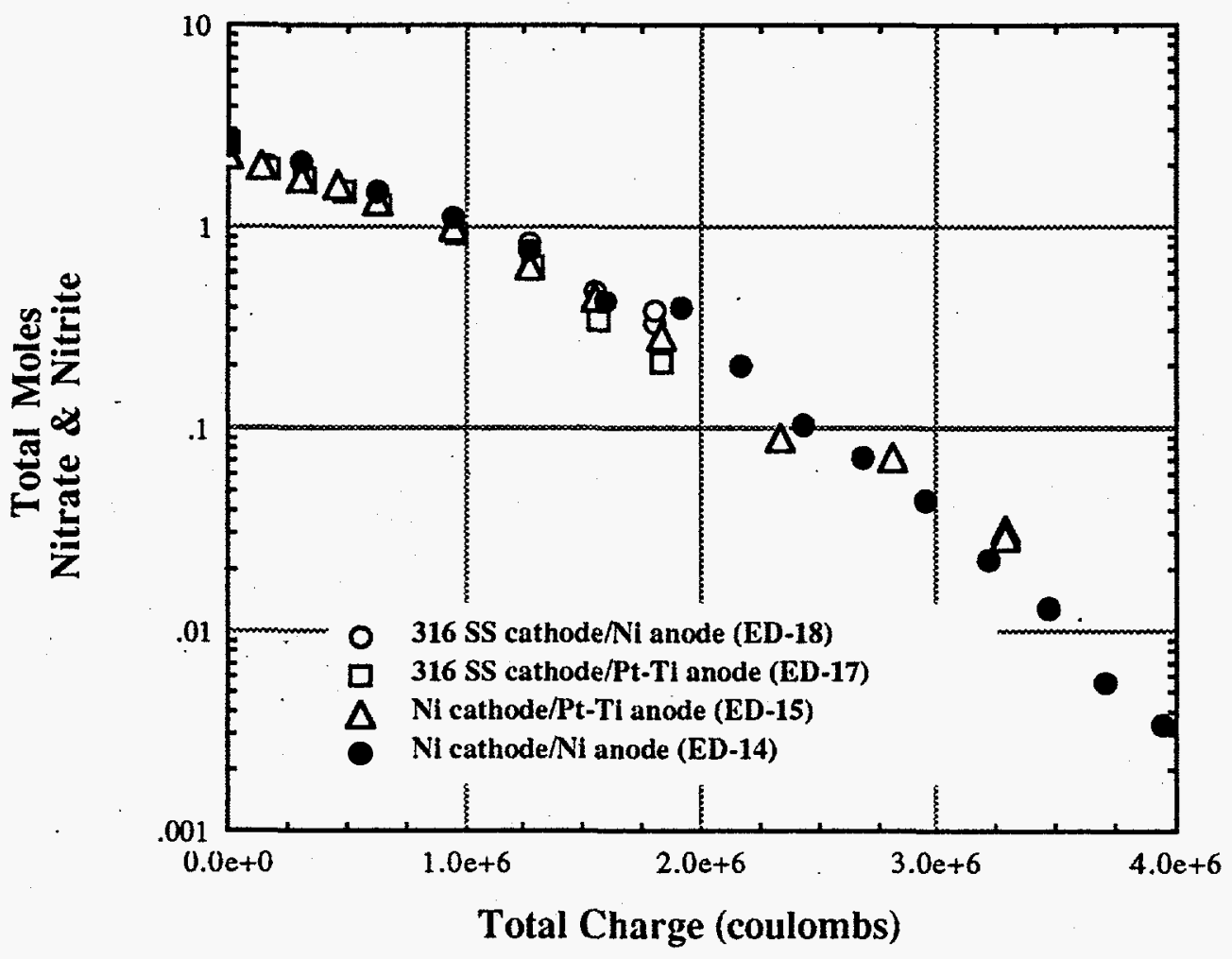




\section{Table VI. Appearance of Surface Films on Electrodes in Divided Cell Tests}

\begin{tabular}{ccl} 
Test \# & Cathode/Anode & \multicolumn{1}{c}{ Appearance } \\
\hline ED-14 & $\mathrm{Ni} / \mathrm{Ni}$ & $\begin{array}{l}\text { black film on cathode and slight brownish tint } \\
\text { on anode }\end{array}$ \\
ED-15 & $\mathrm{Ni} / \mathrm{Pt}-\mathrm{Ti}$ & $\begin{array}{l}\text { grayish film on cathode and slight brownish tint } \\
\text { on anode }\end{array}$ \\
$\mathrm{ED}-17$ & $\mathrm{SS} / \mathrm{Ni}$ & $\begin{array}{l}\text { black film on cathode and slight brownish tint } \\
\text { on anode }\end{array}$ \\
ED-18 & $\mathrm{SS} / \mathrm{Pt}-\mathrm{Ti}$ & $\begin{array}{l}\text { black film on cathode and faint brownish tint on } \\
\text { anode }\end{array}$
\end{tabular}

During electrolysis, hydroxide is one of the products of the reduction of nitrate. The final hydroxide concentration in the catholyte was quite high in the divided cell tests, ranging from $11.4 \mathrm{M}$ to $13.9 \mathrm{M}$ (see Table IV). Figure 5 shows a plot a the moles of hydroxide in the catholyte versus the total charge passed in tests ED-14 through ED-18. Over the course of the four tests, there appeared to be a small decrease in the moles of hydroxide produced per coulomb of charge passed. This decrease may not be a true decrease in the rate of hydroxide production since the nitrate destruction rates were very similar, but reflects an increase in the migration of hydroxide from the catholyte into the anolyte.

A small amount of nitrate and nitrite was detected in the anolyte in the divided cell tests. Nitrate and nitrite will diffuse through the membrane toward the positively charged anode countercurrent to the flow of sodium ion. Diffusion coefficients were calculated for Tests ED-14 through ED-18. The results are provided in Table VII.

Diffusion coefficients for nitrate and nitrite in Nafion ${ }^{\circledR}$ membranes have not been reported in the literature. However, the diffusion of halides (e.g., chloride and iodide) and sulfate has been studied. Diffusion coefficients for chloride, iodide, and sulfate were determined to be $1.5,1.0$, and $4.5 \times 10^{-12} \mathrm{~m}^{2} / \mathrm{s}$, respectively, in $3.0 \mathrm{M} \mathrm{NaCl}$ solution [6]. The rates reported in Table VII appear reasonable for nitrate and nitrite when compared to those for chloride, iodide, and sulfate. There was no apparent change in the diffusion coefficient over the course of these four tests, although the same piece of membrane was used for each test. Thus, no chemical change in the Nafion ${ }^{\circledR}$ Type 350 membrane resulting in a change in the diffusion of nitrate and nitrite occurred during the 152.5 hours of usage. 
Figure 5. Moles of Hydroxide in Catholyte Versus Total Charge (Tests ED-14, ED-15, ED-17, and ED-18)

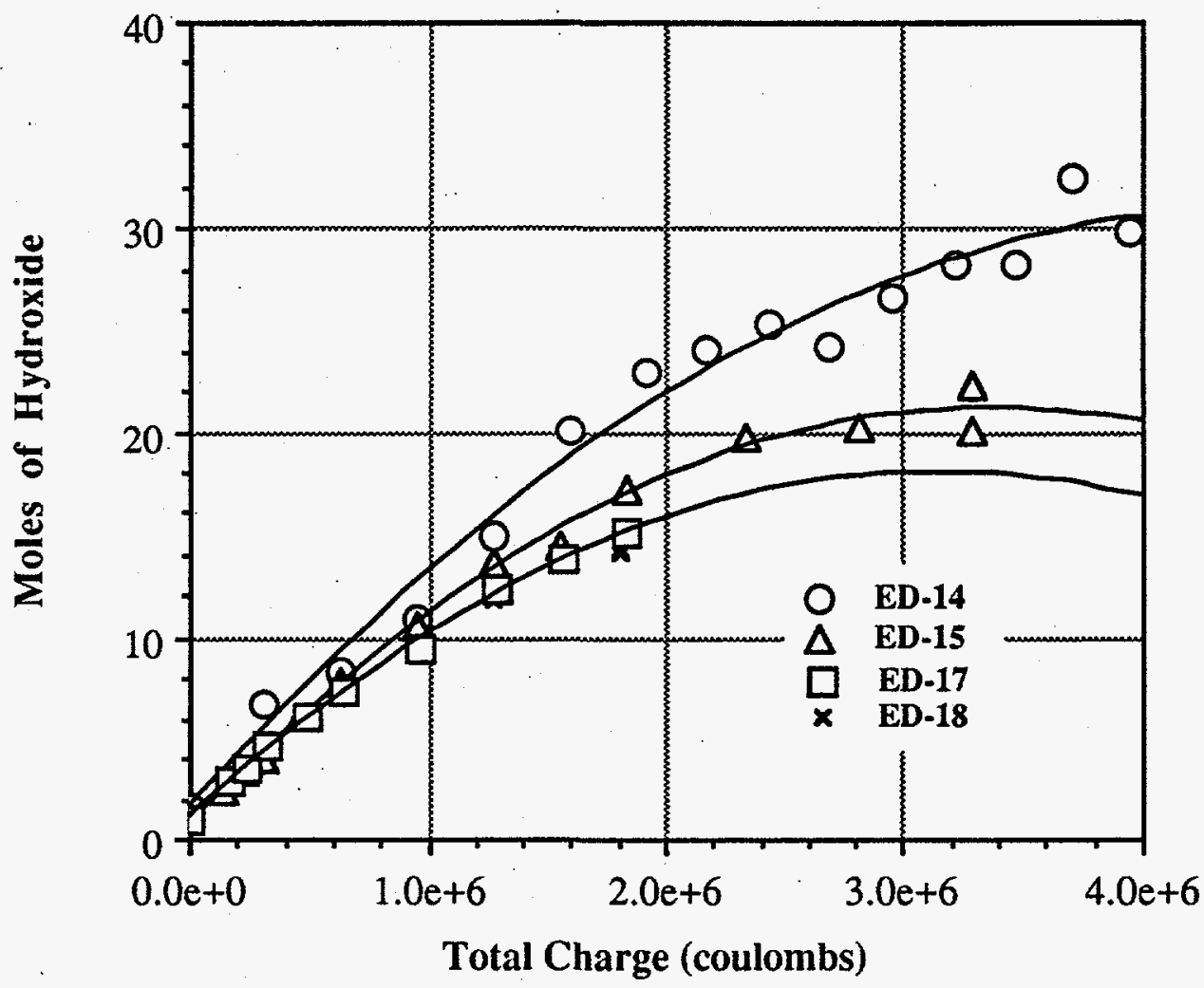

Table VII. Diffusion Coefficients for Nitrate/Nitrate in Divided Cell Tests

$\begin{array}{ll}\text { Test \# } & \mathrm{D}\left(\mathrm{m}^{2} / \mathrm{s}\right) \\ \text { ED-14 } & 2.4 \times 10^{-12} \\ \text { ED-15 } & 4.1 \times 10^{-12} \\ \text { ED-17 } & 6.8 \times 10^{-12} \\ \text { ED-18 } & 3.5 \times 10^{-12}\end{array}$

To maintain charge balance in the divided cell tests, sodium ion is transported from the anolyte across the ion-exchange membrane into the catholyte. Figure 6 shows a plot of the moles of sodium ion in the anolyte and catholyte solutions versus the total charge for the divided cell tests, ED-14 through ED-18. In all four tests, the moles of sodium increased in the catholyte with a concomitant decrease in the anolyte. Note that in tests ED-17 and ED-18, the initial volume of the anolyte was about $3.6 \mathrm{~L}$ versus $8.0 \mathrm{~L}$ for tests ED-14 and ED-15. Because of the lower initial anolyte volume, the total moles of 
sodium ion in the anolyte for the latter two tests was about $50 \%$ lower than that in the first two tests.

Figure 6. Moles of Sodium in Catholyte and Anolyte Solutions Versus Total Charge for Tests ED-14, ED-15, ED-17, and ED-18

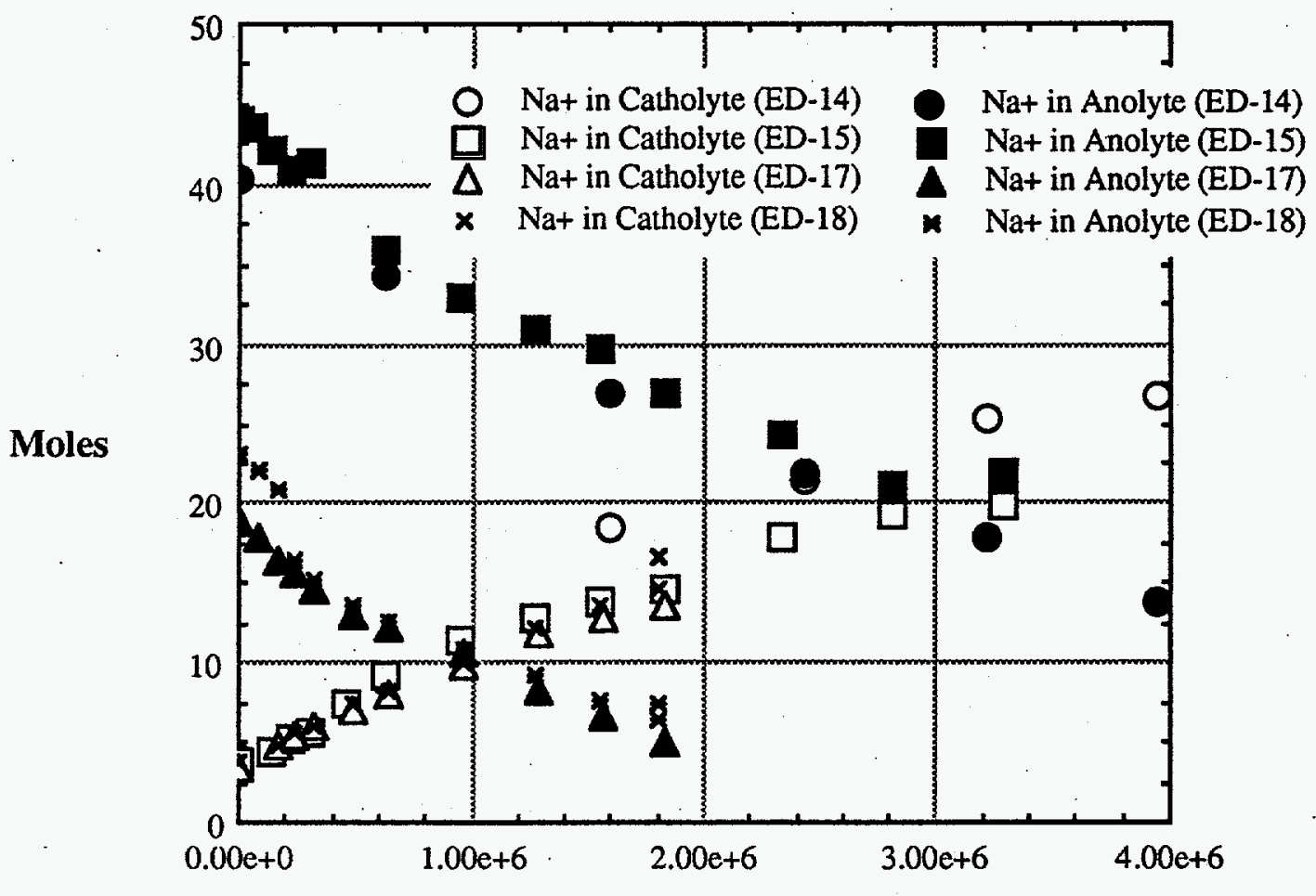

Total Charge (coulombs)

\section{Undivided Cell Tests}

Figure 7 shows a plot of the total moles of nitrate and nitrite versus the total charge passed for the six tests carried out in an undivided cell configuration. Three cathode materials -- nickel, Type 316 stainless steel, and lead -- and two anode materials -- nickel and platinized titanium -- were tested.

As in the case of the divided cell tests, the cell voltage in the undivided cell tests was independent of cathode material, but dependent on the anode material. When platinized titanium was used as the anode, the cell voltage was about 1.1 volts higher than when nickel was used. Thus, at a current density of $3500 \mathrm{amps} / \mathrm{m}^{2}$, the electrical power requirement for a reactor equipped with platinized titanium anodes would consume about $30 \%$ more power than one equipped with nickel anodes.

The undivided cell tests were carried out a higher current density $\left(5000 \mathrm{amps} / \mathrm{m}^{2}\right)$ than most of the divided cell tests (3500amps $/ \mathrm{m}^{2}$ ). Thus, direct comparison of cell voltages is difficult. From results of the divided cell tests ED-11, ED-12, ED-13, and ED-14, the cell voltage at $5000 \mathrm{amps} / \mathrm{m}^{2}$ is not appreciably higher than that at $3500 \mathrm{amps} / \mathrm{m}^{2}$. Assuming this to be the case for undivided cell operation, the cell voltage for the 
undivided tests ranged from 1.3 to 1.6 volts lower than the corresponding tests conducted with the Nafion ${ }^{\circledR}$ separator. Thus, the use of the $\mathrm{Nafion}^{\circledR}$ separator will increase in the power consumption of the electrochemical reactor by about $30-47 \%$.

\section{Figure 7. Total Moles of Nitrate and Nitrite Versus Total Charge for Tests ED-19 through ED-24}

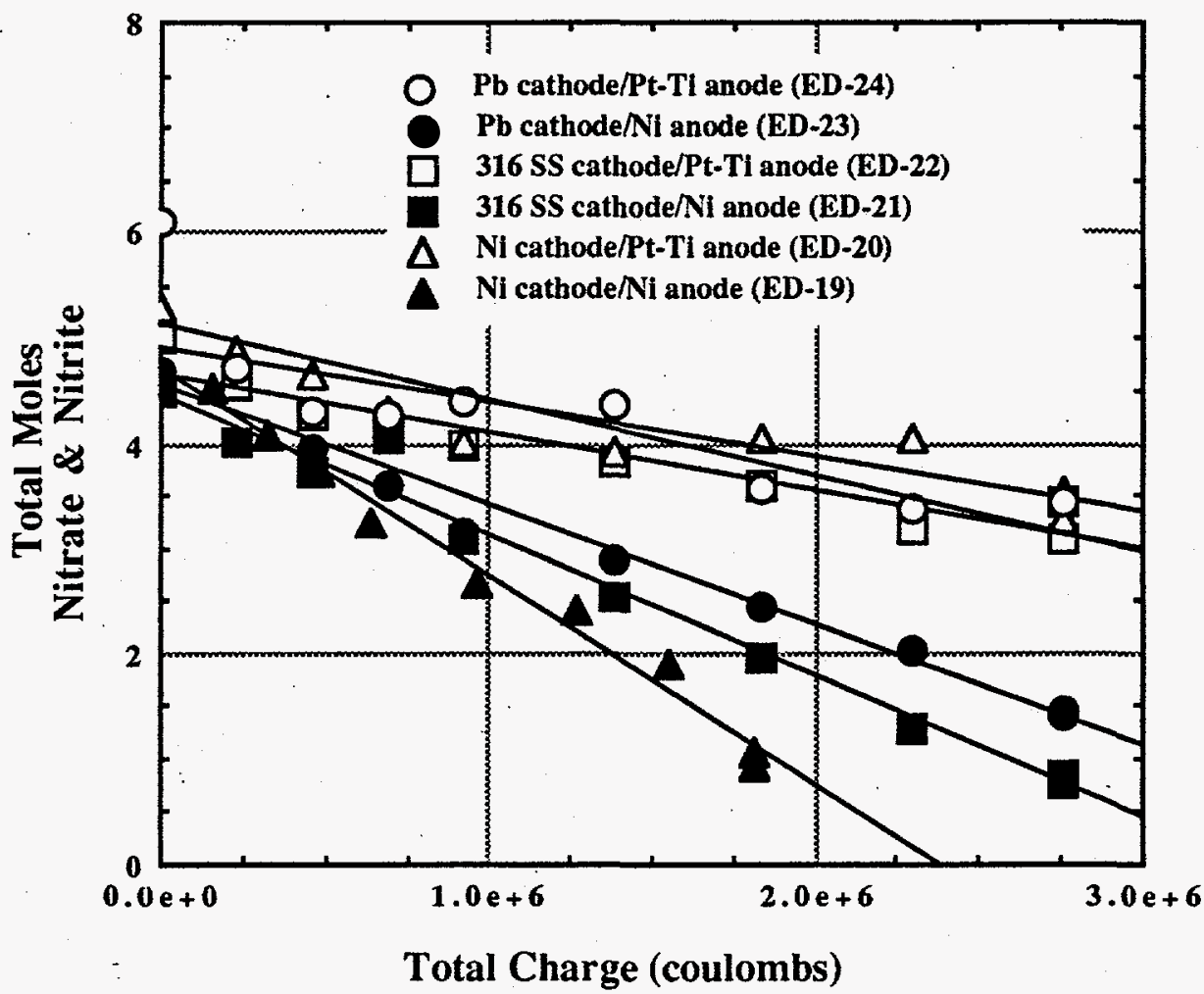

From a linear regression of the data, the rate of nitrate and nitrite destruction for each test was determined. The results are provided in Table VIII. More rapid nitrate destruction was observed in the tests utilizing a nickel anode versus those with a platinized titanium anode. This is consistent with test results recently reported by the Pacific Northwest Laboratory [9]. Apparently the oxidation of nitrite is much more rapid on platinum than on nickel. As a result, less nitrate is reduced per quantity of charge passed.

The rates of nitrate destruction using a lead cathode and nickel anode or a Type 316 stainless steel cathode and nickel anode were similar to the rates observed in the divided cell tests and in previous tests $[1,2]$. The most rapid nitrate destruction rate was observed with a nickel cathode and nickel anode (ED-19). This result is somewhat surprising in view of previous results with nonradioactive simulants $[1,2]$. The higher destruction rate with the ETF waste is attributed to the low $\mathrm{Cr}(\mathrm{VI})$ content. As a result of the low $\mathrm{Cr}(\mathrm{VI})$ content, the formation of $\mathrm{Cr}$ (III) hydroxide films on the nickel cathode that interfere with nitrate and nitrite reduction reactions is reduced. Thus, there is more rapid nitrate destruction since there is no interference from $\mathrm{Cr}$ (III) hydroxide films. 
Table VIII. Rate of Nitrate \& Nitrite Destruction in Undivided Cell Tests

$\begin{array}{lllc}\text { Test \# } & \text { Cathode/Anode } & \mathbf{k} \text { (mole/C) } & \begin{array}{c}\text { Current }^{\mathrm{a}} \\ \text { Efficiency }^{(\%)}\end{array} \\ \text { ED-19 } & \mathrm{Ni} / \mathrm{Ni} & 1.98 \times 10^{-6} & 96 \\ \mathrm{ED}-20 & \mathrm{Ni} / \mathrm{Pt}-\mathrm{Ti} & 5.30 \times 10^{-7} & 26 \\ \mathrm{ED}-21 & 316 \mathrm{SS} / \mathrm{Ni} & 1.34 \times 10^{-6} & 65 \\ \mathrm{ED}-22 & 316 \mathrm{SS} / \mathrm{Pt}-\mathrm{Ti} & 5.60 \times 10^{-7} & 27 \\ \text { ED-23 } & \mathrm{Pb} / \mathrm{Ni} & 1.15 \times 10^{-6} & 56 \\ \text { ED-24 } & \mathrm{Pb} / \mathrm{Pt}-\mathrm{Ti} & 7.36 \times 10^{-7} & 36\end{array}$

a calculated assuming nitrogen is only nitrate/nitrite reduction product $\left(2.07 \times 10^{-6} \mathrm{~mole} /\right.$ coulomb $)$

No evidence for attack of cell components, including electrodes and gaskets, was observed in the undivided cell tests. Similar films were observed on the surfaces of the cathodes and anodes in the undivided cell tests as were observed in the divided cell tests. A strongly adhering black film was present on all the cathodes after each test. The films were not removed by rinsing with deionized, distilled water or detergent and water, but were removed by briefly soaking and rinsing theelectrodes in $2 \mathrm{M}$ nitric acid. A description of the appearance of the surface films are provided in Table IX.

Table IX. Appearance of Surface Films on Electrodes in Undivided Cell Tests

\begin{tabular}{|c|c|c|}
\hline Test \# & Cathode/Anode & Appearance \\
\hline ED-19 & $\mathrm{Ni} / \mathrm{Ni}$ & black film on cathode and thin black film on anode \\
\hline ED-20 & $\mathrm{Ni} / \mathrm{Pt}-\mathrm{Ti}$ & black film on cathode and no visible coating on anode \\
\hline ED-21 & $316 \mathrm{SS} / \mathrm{Ni}$ & $\begin{array}{l}\text { black film on cathode and slight brown tarnishing on } \\
\text { anode }\end{array}$ \\
\hline ED-22 & $316 \mathrm{SS} / \mathrm{Pt}-\mathrm{Ti}$ & black film on cathode and no visible coating on anode \\
\hline ED-23 & $\mathrm{Pb} / \mathrm{Ni}$ & black film on cathode and no visible coating on anode \\
\hline ED-24 & $\mathrm{Pb} / \mathrm{Pt}-\mathrm{Ti}$ & black film on cathode and no visible coating on anode \\
\hline
\end{tabular}

Energy Requirements and Electricity Costs

The energy requirements and electricity costs for treating the ETF concentrate were calculated using the experimental results. Five cases were selected: (1) the fastest reaction rate (undivided cell with nickel cathode and nickel anode), (2) the average of the three undivided cell tests with a nickel anode, (3) the average of the three undivided cell tests with a platinized titanium anode, (4) the average of the two divided cell tests with a nickel anode, and (5) the average of the two divided cell tests with a platinized titanium anode. The results are shown in Table X. 
Table X. Energy Requirements and Costs for the Electrochemical Denitration of the ETF Concentrate

\begin{tabular}{|c|c|c|c|}
\hline Case & Description & $\begin{array}{l}\text { Energya } \\
(\mathrm{kwh} / \mathrm{L})\end{array}$ & $\begin{array}{l}\text { Costb } \\
(\$ / L)\end{array}$ \\
\hline 1 & fastest rate (ED-19) & 1.8 & 0.09 \\
\hline 2 & average undivided cell with $\mathrm{Ni}$ anode & 2.3 & 0.12 \\
\hline 3 & average undivided cell with $\mathrm{Pt}-\mathrm{Ti}$ anode & 7.6 & 0.38 \\
\hline 4 & average divided cell with $\mathrm{Ni}$ anode & 4.1 & 0.20 \\
\hline 5 & average divided cell with $\mathrm{Pt}-\mathrm{Ti}$ anode & 5.1 & 0.26 \\
\hline
\end{tabular}

The energy requirements and electricity costs for treating the ETF concentrate based on the experimental results varied by a factor of 4.2. The largest variation existed for the undivided cell configuration due to a combination of the variation in the destruction rates and the cell potentials. The variation for the divided cell configuration was about $24 \%$ largely due to the difference in the cell potential between the nickel and platinized titanium anodes. Clearly, the use of platinized titanium in either the undivided or divided cell configurations increases the energy and costs required to achieve nitrate destruction.

\section{CONCLUSIONS}

Electrochemical destruction of nitrate in actual SRS waste has been demonstrated in a bench-scale flow cell reactor. Greater than $99 \%$ of the nitrate can be destroyed in either an undivided or a divided cell reactor. The rate of destruction as well as the power requirements and costs are dependent on the cell configuration and electrode materials. The fastest destruction rate for combined nitrate and nitrite was observed with an undivided cell equipped with a nickel cathode and nickel anode. The use of a platinized titanium anode increased the energy requirement and costs compared to a nickel anode in both the undivided and divided cell configurations.

\section{ACKNOWLEDGMENTS}

The author wishes to acknowledge H. L. Thacker for his efforts in fabricating the experimental equipment and conducting the tests reported in this document. This work was funded by the Office of Technology Development, Office of Environmental Management through the Efficient Separations and Processing Integrated Program, Teresa B. Fryberger, Headquarters Program Manager, and Allison M. Blackmon, cognizant Technical Program Officer.

\section{QUALITY ASSURANCE}

All work reported in this document was carried out in accordance with the requirements specified in the Task and Quality Assurance Plan for the Electrochemical Testing of Liquid Radioactive Wastes [10]. Experimental data are recorded in laboratory notebooks WSRC-NB-93-152 and WSRC-NB-94-325. 


\section{TECHNICAL REVIEW}

$\frac{\int \sum \text { Whte }}{4 / 26 / 95}$

\section{APPROVAL}

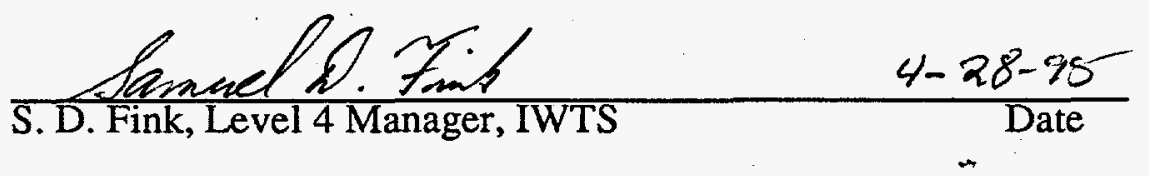

\section{REFERENCES}

1. J. D. Genders, "Final Report - Electrochemical Processing Of Nitrate Waste Solutions (U)," May 31, 1990 (WSRC-TR-90-491).

2. J. D. Genders, N. Weinberg, and D. Hartsough, "Phase II Final Report -

Electrochemical Processing Of Nitrate Waste Solutions, (U)" October 7, 1992 (WSRC-TR-93-090).

3. D. T. Hobbs, "Electrochemical Treatment of Nuclear Waste at the Savannah River Site," Chapter 12 in Electrochemistry For A Cleaner Environment, edited by J. D. Genders and N. L. Weinberg, Electrosynthesis Company, Inc., East Amherst, New York, 1992.

4. D. T. Hobbs, "Electrochemical Treatment of Akaline Nuclear Wastes," presented at the 208th Meeting of the American Chemical Society, Washington, DC, August 24, 1994.

5. D. T. Hobbs, "Summary Technical Report on the Electrochemical Treatment of Alkaline Nuclear Wastes (U)," WSRC-TR-94-0287, July 30, 1994.

6. A. Herrera and H. L. Yeager, J. Electrochem. Soc., 134(10), 2446 (1987).

7. J. Kim and J. O'M. Bockris, SCUREF Monthly Status Report - Task Order \#112, May, 1994.

8. J. Kim and J. O'M. Bockris, SCUREF Monthly Status Report - Task Order \#1112, December, 1994.

9. W. E. Lawrence, J. E. Surma, M. F. Buehler, J. H. Sukamto, G. Pillay, K. L. Gervais, K. N. Sasser, and M. D. Ryder, "Final Report Electrochemical Organic/Complexant Destruction in Hanford Tank Waste Simulant," December, 1994 (WSRC-RP-95-111).

10. D. T. Hobbs, "Task and Quality Assurance Plan for the Electrochemical Testing of Liquid Radioactive Wastes, ". WSRC-RP-93-1496, November 15, 1993. 
Distribution:

T. B. Fryberger, DOE-HQ

A. M. Blackmon, DOE-SR, 703-A

M. G. Schwenker, DOE-SR, 704-H

W. L. Kuhn, PNL

J. E. Surma, PNL

W. E. Lawrence, PNL

P. A. Taylor, ORNL

K. Wendt, LITCO

D. Croson, LITCO

R. E. White, University of South Carolina

J. W. Van Zee, University of South Carolina

J. O.'M. Bockris, Texas A\&M

J. D. Genders, Electrosynthesis Company

L. M. Papauchado, 773-A

C. R. Wolf, 773-A

W. L. Tamosaitis, 773-A

S. D. Fink, 773-A

J. L. Steimke, 786-5A

R. F. Swingle, 773-A

D. J. McCabe, 773-A

J. E. Marra, 703-H

J. R. Fowler, 704-Z

IWT-LWP File, 773-A

TIM, 773-52A 